\title{
A New Chemical Constituent from the Hairy Root Cultures of Catharanthus roseus
}

\author{
Ill-Min Chung, ${ }^{a}$ Han-Young Park, ${ }^{a}$ Mohd Ali, ${ }^{+}$Ka Yiu San, ${ }^{\ddagger}$ \\ Christie A. M. Peebles, ${ }^{\ddagger}$ Seung-Beom Hong, and Ateeque Ahmad ${ }^{\circ}$ \\ Department of Applied Life Science, Konkuk University, Seoul 1+3-701. Korea. "E-mail: aahmadciă vahoo com \\ -Faculty of Pharmact, Hamdard Universit, New Delhi 110062. India \\ ${ }^{\ddagger}$ Department of Bioengineering, Rice Cniversin; Houston, Texas 77005 . LSA \\ Received November 6, 2006
}

\begin{abstract}
One new compound, 3.7.11.19,23.27-hexamethyl-15-hydroxymethylene-n-octacos-5,8.20-triene-10 $\beta .18 \alpha$ diol-10 $\beta$-D-glucopyranoside (1). along with the three known compounds, 3-epibetulinic acid (2). n-pentadecanyl octa-dec-19-en-oate (3) and $\beta$-sitosterol (4) were isolated from the methanolic extract of the cultured Cafharanthus roseus hairy roots. The structures of the one new and three known conpounds were elucidated using one- and two-dimensional NMR in combination with IR, EI/MS. FAB/MS. To the best of our knowledge, $3,7,11,19.23 .27$-hexamethyl-15-hy droxy methylene-n-octacos-5.8.20-triene-10 $\beta .18 \alpha$-diol-10 $\beta$-D-glucopyranoside. 3 -epibetulinic acid and $n$-pentadecanyl octa-dec-19-en-oate were identified for the first time from the hairy roots of $C$, roseus.
\end{abstract}

Key Words : Catharanthis rosets. Apocynaceae. Culture hairy root composition. New and known compounds

\section{Introduction}

The periwinkle. Catharanthus rosets (Apocynaceae). is widely used onamental plant as well as medicinal plant. $C$. rosetis is a herbaceous slrub ${ }^{1}$ and has been extensively studied due to its production of two valuable alkaloids. vincristine and vinblastine which are used in the treatment of human neoplasm. and an alkaloid from the root. ajmalicine which is used in the treatment of circulatory disorders and hypertension. Biologically indole alkaloids produced by plants are believed to play a role as antimicrobial and antifeeding compounds. ${ }^{2.3}$ This Madagascan periwinkle produces numerous indole alkaloids which have important therapeutic activities. ${ }^{4}$ Only few phenolic compounds have been reported in this genus. ${ }^{5}$ Recently. two flavonols trisaccharides of kaenipferol and quercetin have isolated and identified. ${ }^{7}$ Several indole alkaloids have been isolated from the $C$. roset $s$ cell suspension cultures ${ }^{8.5}$ However. the production of the most valuable compounds reported from this plant, vincristine and vimblastine that are terpenoid indole alkaloids, ${ }^{10}$ has not yet been achieved in these cultures. Besides indole alkaloids, the presence of anthocyanidins. ${ }^{11}$ phenolics, ${ }^{312}$ and terpenoid compounds $s^{3,5}$ in the cultures of C. rosents has been reported. As part of its secondary metabolism this plant produces pharmaceutically valuable terpenoid indole alkaloids such as vincristine and vimblastine which are used as anticancer drugs. A very low yield of these compounds is a major motivation of the research interest in this plant. Although the hairy root cultures do not produce these two bisindole alkaloids that consist of catharanthine and vindoline. they have been shown to produce catharanthine and tabersonine. This paper deals with the isolation and structural elucidation of one new compound (1) and three known compounds (2-4) from the cultured

${ }^{a}$ These two authors are equally contributed to this study hairy roots of $C$ rosets on the basis of spectral data and chemical reactions. Previously compound $\mathbf{2}$ and $\mathbf{3}$ are not reported with the complete spectral data and these compounds have reported for the first time from this cultured
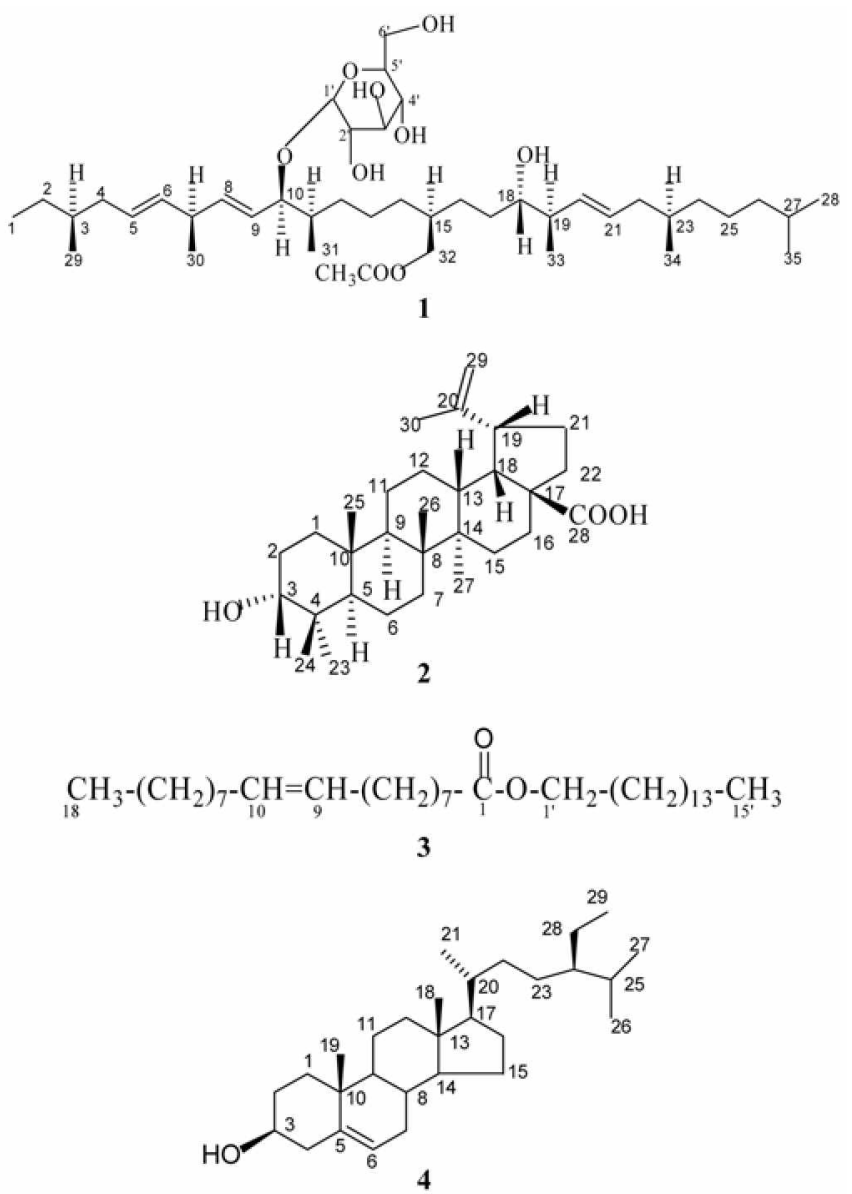

Figure 1. Chemical structures of 1-4. 
roots. Also, this is the first report of the isolation of chemical compounds from the hairy root cultures of $C$. rosets. Due to high significance of medicinal natural products of this plant roots the work in this area has already been done. The aim of the present investigation is to report some of the new findings in the form of natural product from roots along with some known compounds. Further investigations and other isolated fractions are in progress.

\section{Results and Discussion}

Compound 1 was obtained as a light yellow semisolid crystalline mass. It responded positive tests for glycosides. Its IR spectrum showed characteristic absorption bands for hydroxyl groups $\left(3420.3390 .3285 \mathrm{~cm}^{-1}\right)$, ester group (1736 $\left.\mathrm{cm}^{-1}\right)$, and unsaturation $\left(1640 \mathrm{~cm}^{-1}\right)$. Its FAB mass spectrum displayed a molecular ion peak at $m \geq 738$ corresponding to $\mathrm{C}_{43} \mathrm{H}_{78} \mathrm{O}_{9}$. Elimination of glycosidic unit from the $[\mathrm{M}]^{+}$ generated an aglycone at $m z 576\left[\mathrm{C}_{37} \mathrm{H}_{68} \mathrm{O}_{4}\right]^{+}$and removal of the acetyl group from this unit produced a mass ion at $m z$ 533. The prominent ion peaks arose at $m z 476.57\left[\mathrm{C}_{3}-\mathrm{C}_{4}\right.$ fission $]^{-}, 462,71\left[\mathrm{C}_{4}-\mathrm{C}_{5} \text { fission }\right]^{+} .436 .97\left[\mathrm{C}_{6}-\mathrm{C}_{7} \text { fission }\right]^{-}$. $151.382\left[\mathrm{C}_{5}-\mathrm{C}_{10} \text { fission }\right]^{+} .181$, and $352\left[\mathrm{C}_{10}-\mathrm{C}_{11} \text { fission }\right]^{+}$ supported the existence of vinylic linkages at $\mathrm{C}-5$ and $\mathrm{C}-8$ and one of the hydroxyl groups at $\mathrm{C}-10$. The ion peak at $m z$ 251 and $282\left[\mathrm{C}_{14}-\mathrm{C}_{15} \text { fission }\right]^{+} .295$ and $238\left[\mathrm{C}_{15}-\mathrm{C}_{16}\right.$ fission $]^{-}, 210$ and $323\left[\mathrm{C}_{17}-\mathrm{C}_{15} \text { fission }\right]^{-}$, and 180 and 353 $\left[\mathrm{C}_{18}-\mathrm{C}_{15} \text { fission }\right]^{+}$suggested the location of the hydroxyl group at $\mathrm{C}-18$ and the $U$-acetyl group at $\mathrm{C}-32$. The ion peaks yielded at $m z 381$ and $152\left[\mathrm{C}_{19}-\mathrm{C}_{20} \text { fission] }\right]^{-}, 127$ and 407 $\left[\mathrm{C}_{21}-\mathrm{C}_{22} \text { fission }\right]^{+}, 113$ and $420\left[\mathrm{C}_{2:}-\mathrm{C}_{23} \text { fission }\right]^{+}$. and 85 and $448\left[\mathrm{C}_{33}-\mathrm{C}_{24} \text { fission }\right]^{+}$indicated the existence of the remaining viny lic linkage at $\mathrm{C}-20$. The fragmentation pattern of 1 is shown in Figure 2

The ${ }^{1} \mathrm{H}-\mathrm{NMR}$ spectrum of $\mathbf{1}$ exhibited three multiplet signals at $\delta 5.34 .53 .35$. and 5.36 were integrated for two protons each. assigned to vinylic $\mathrm{H}-5$ and $\mathrm{H}-9$. $\mathrm{H}-6$ and $\mathrm{H}-$ 20. and H-8 and H-21, respectively: A doublet of doublet signal at $\delta 3.51(1 \mathrm{H} . J=9.0 .9 .0 \mathrm{~Hz})$ and a doublet of double doublet signal at $\delta 3.46(\mathrm{lH}, J=3.5,5.5 .4 .0 \mathrm{~Hz})$ were ascribed to $\mathrm{H}-10$ and $\mathrm{H}-18$. respectively. Two $\mathrm{lH}$ doublet signals at $\delta 3.84(J=6.5 \mathrm{~Hz})$ and $3.81(J=6.5 \mathrm{~Hz})$ were attributed to the two protons attached to $\mathrm{C}-32$. Four $\mathrm{IH}$ doublet signals at $\delta 4.36(J=8.0 \mathrm{~Hz}) .4 .32(J=3.5 \mathrm{~Hz}), 3.02$ $(J=6.5 \mathrm{~Hz})$, and $3.00(J=6.5 \mathrm{~Hz})$. two $\mathrm{lH}$ double doublet signals at $\delta 3.44(J=4.0 .3 .5 \mathrm{~Hz})$ and $3.46(J=3.5 .5 .5 \mathrm{~Hz})$. and a $\mathrm{IH}$ multiplet signal at $\delta 3.54$ were accounted to the sugar protons. A broad $3 \mathrm{H}$ signal at $\delta 2.40$ was associated with the acetyl group. A $3 \mathrm{H}$ triplet at $\delta 0.76(J=6.0 \mathrm{~Hz})$ was assigned to primary methyl protons attached to $\mathrm{C}-\mathrm{L}$. A broad signal at $\delta 0.67$ was ascribed to six protons attached to $\mathrm{C}-28$ and $\mathrm{C}-35$. Five $3 \mathrm{H}$ doublets at $\delta 0.79(J=6.0 \mathrm{~Hz}), 0.91(J=$ $6.0 \mathrm{~Hz}) .0 .80(J=6.5 \mathrm{~Hz}) .0 .89(J=6.5 \mathrm{~Hz})$. and $0.86(J$ $=7.0 \mathrm{~Hz}$ ) were associated with the methyl protons attached to $\mathrm{C}-29, \mathrm{C}-30, \mathrm{C}-31, \mathrm{C}-33$ and $\mathrm{C}-34$, respectively. The remaining methylene and methine protons resonated between $\delta$ 2.33-1.25. The ${ }^{13} \mathrm{C}-\mathrm{NMR}$ spectrum of 1 showed
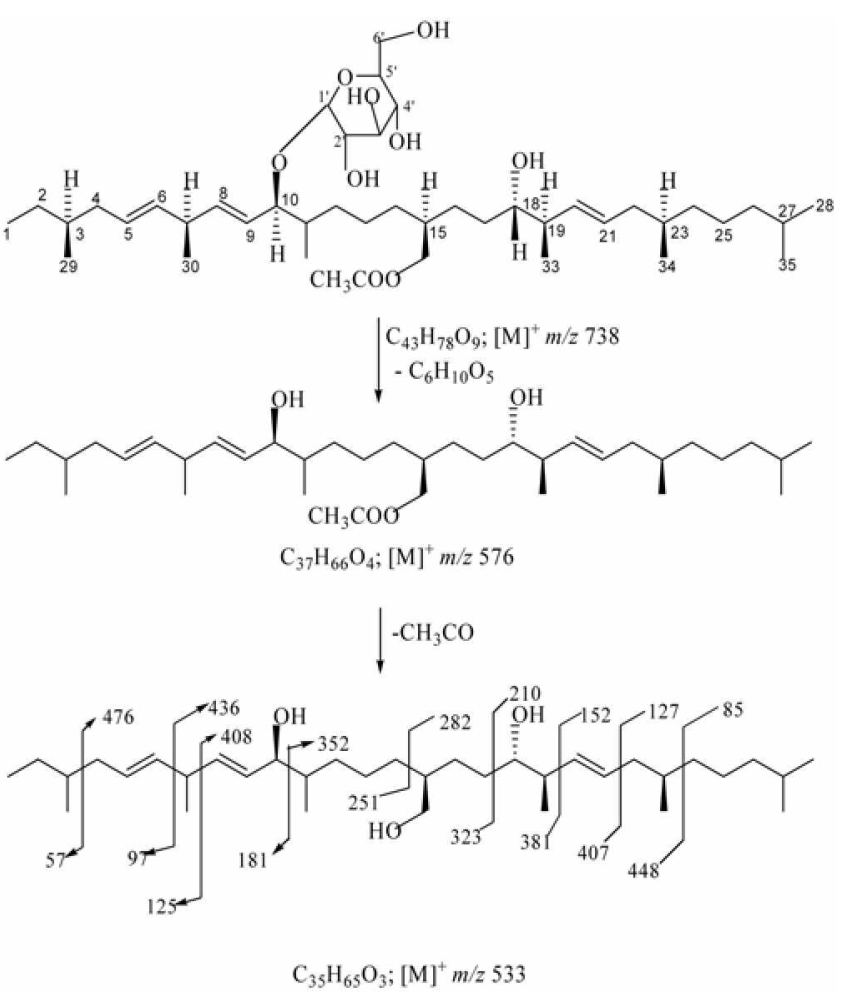

Figure 2. Fragmentation pattems of compound 1.

important signals for vinylic carbons at $\delta 130.21$ (C-5). 129.91 (C-6). 138.47 (C-8). 150.15 (C-9). 128.10 (C-20). and $122.26(\mathrm{C}-21)$. for tertiary carbons at $\delta 70.57(\mathrm{C}-10)$ and 70.45 (C-18), for two methylene carbons attached to oxygen atoms at $\delta 63.73(\mathrm{C}-32)$ and $63.10\left(\mathrm{C}-6^{\prime}\right)$. for the anomeric carbon at $\delta 101.45\left(\mathrm{C}-\mathrm{I}^{\prime}\right)$, for the remaining sugar carbons at $\delta 76.46\left(\mathrm{C}-2^{\prime}\right), 74.03\left(\mathrm{C}-3^{\prime}\right), 73.74\left(\mathrm{C}-4^{\prime}\right)$. and $79.83\left(\mathrm{C}-5^{\prime}\right)$. for the methyl carbons at $\delta 19.54$ (C-28). 14.31 (C-29), 21.43 (C-30). 19.09 (C-31). 18.44 (C-33). 18.90 (C-34). and 15.07 (C-35), and for the primary methyl carbon at $\delta 12.05$ (C-1). The remaining methylene and methine carbons resonatated between $\delta 56.97-72.88$. Two carbon signals at $\delta$ 174.55 and 34.43 were attributed to the acetyl group. The multiplicity of each carbon was detenmined by DEPT experiments. There were nine primary. 13 methylene. 20 methine. and one quaternary carbon in the molecule. The HMBC shows the correlation between the anomeric proton of the glucose and C-10. This indicates that the sugar moiety is attached to C-10. Also. H-32 and methyl protons in the $O$ acetyl group showed the correlation with the carbonyl carbon. These correlations presented the attached position (C-32) of the O-acetyl group. The carbon signals of C-9 correlated with $\mathrm{H}-8, \mathrm{H}-7$, and $\mathrm{H}-10$ and of $\mathrm{C}-18$ correlated with $\mathrm{H}-19$ and $\mathrm{H}-20$ were found in the HMBC spectrum. The ${ }^{1} \mathrm{H}-{ }^{1} \mathrm{H}$ COSY spectrum of 1 exhibited the linear connection patterns between $\mathrm{H}_{-1} \mathrm{I}^{\prime}, \mathrm{H}-2^{\prime}, \mathrm{H}-3^{\prime}$. and $\mathrm{H}^{-5^{\prime}}$, between $\mathrm{H}$ 30. $\mathrm{H}-7 . \mathrm{H}-6$, and $\mathrm{H}-5$, between $\mathrm{H}-30$. $\mathrm{H}-8$, and $\mathrm{H}-9$, between $\mathrm{H}-18, \mathrm{H}-17$, and $\mathrm{H}-16$, and between $\mathrm{H}-18, \mathrm{H}-19$, and $\mathrm{H}-20$. Acid hydrolysis of 1 yielded D-glucose which was determined by co-TLC with an authentic sample of Dglucose. On the basis of the foregoing account the structure 
of 1 has been established as 3,7.11.19.23.27-hexamethyl-15hydroxymethy lene- 7 -octacos-5,8.20-triene-10, 18-diol-10- $\beta$ $\mathrm{D}$-glucopyranoside. This is a new compound isolated from the cultured hairy roots of $C$. rosetis.

Compound 2.3-epibetulinic acid. was obtained as a colorless crystalline mass from the $\mathrm{CHCl}_{3}-\mathrm{MeOH}(95: 5)$ eluent sy stem. It responded positively to Liebermann-Burchard test for triterpnes. Its IR spectrum showed characteristic absorption bands for hydroxyl group $\left(3448 \mathrm{~cm}^{-1}\right)$, carboxylic group $\left(1688 \mathrm{~cm}^{-1}\right)$. and unsaturation $\left(1640 \mathrm{~cm}^{-1}\right)$. The EI and positive ion $\mathrm{FAB}$ mass spectra established the molecular ion peak at $m z 456$ which is corresponding to a molecular formula $\mathrm{C}_{3 i} \mathrm{H}_{4} \mathrm{O}_{3}$. It indicated seven double bond equivalents: five of them were adjusted in the pentacyclic carbon frame-work of triterpene and one each in the vinylic linkage and carboxylic group. The prominent ion peaks arose at $m z$ $100.356\left[\mathrm{C}_{1}-\mathrm{C}_{10} \text { fission }\right]^{+} .82\left[100-\mathrm{H}_{2} \mathrm{O}\right]^{-}, 113\left[\mathrm{C}_{1.10}-\mathrm{C}_{5.10-}\right.$ $\mathrm{C}_{5.6}$ fission $]^{-}, 95\left[113-\mathrm{H}_{2} \mathrm{O}\right]^{+} .109\left[\mathrm{C}_{1.10}-\mathrm{C}_{5.10}-\mathrm{C}_{6.7}\right.$ fission$\left.\mathrm{H}_{2} \mathrm{O}\right]^{-}, 55\left[\mathrm{C}_{3.4}-\mathrm{C}_{5.10}-\mathrm{C}_{56} \text { fission }\right]^{+} .69\left[\mathrm{C}_{3.4}-\mathrm{C}_{5.10}-\mathrm{C}_{6.7}\right.$ fission $]^{-}, 83\left[\mathrm{C}_{3.4}-\mathrm{C}_{5.10}-\mathrm{C}_{7.8} \text { fission }\right]^{+}$. and $123\left[\mathrm{C}_{1.101}-\mathrm{C}_{5.10}\right.$ $-\mathrm{C}_{7.8}$ fission $\left.-\mathrm{H}_{2} \mathrm{O}\right]^{-}$. This suggested the location of hydroxyl group in ring A which was placed at $\mathrm{C}-3$ on the basis of biogenetic grounds. The ion peaks generated at $m z 208.248$ $\left[\mathrm{C}_{8.14}-\mathrm{C}_{9.11} \text { fission] }\right]^{+} .190\left[208-\mathrm{H}_{2} \mathrm{O}\right]^{-}, 203[248-\mathrm{COOH}]^{-}$. $207\left[248-\mathrm{C}_{3} \mathrm{H}_{5}\right]^{+} .234 .222\left[\mathrm{C}_{8.14}-\mathrm{C}_{11.12} \text { fission }\right]^{+} .189[234$ $-\mathrm{COOH}]^{+} .204\left[222-\mathrm{H}_{2} \mathrm{O}\right]^{+} .220 .236\left[\mathrm{C}_{8.14}-\mathrm{C}_{12.13}\right.$ fission] ${ }^{-}$. $175[220-\mathrm{COOH}]^{+} .218\left[236-\mathrm{H}_{-} \mathrm{O}\right]^{-}$. and $221\left[236-\mathrm{Me}^{+}\right.$ which suggested the saturated nature of ring $\mathrm{C}$. The ion peaks arose at $m z 304.152\left[\mathrm{C}_{16.17}-\mathrm{C}_{13.18} \text { fission }\right]^{+} .107$ $[152-\mathrm{CONH}]^{+}, 286\left[304-\mathrm{H}_{2} \mathrm{O}\right]^{+}, 272\left[286-\mathrm{CH}_{2}\right]^{+}, 258$ $\left[272-\mathrm{CH}_{2}\right]^{-} .121\left[\mathrm{C}_{15.16}-\mathrm{C}_{13.18} \text { fission- } \mathrm{COOH}\right]^{-} .135\left[\mathrm{C}_{14.15}\right.$ $-\mathrm{C}_{13.18}$ fission- $\left.\mathrm{COOH}\right]^{-} .441[\mathrm{M}-\mathrm{Me}]^{+}, 438\left[\mathrm{M}-\mathrm{H}_{2} \mathrm{O}\right]^{-} .423$ $\left[438-\mathrm{H}_{2} \mathrm{O}\right]^{+} .41 \mathrm{l}[\mathrm{M}-\mathrm{COOH}]^{-}, 395\left[411-\mathrm{Me}^{+}\right.$, and 410 $[\mathrm{M}-\mathrm{HCOOH}]^{+}$indicated the saturated nature of ring $\mathrm{D}$ and attachment of the carboxylic group at C-28. The fragmentation pattern of $\mathbf{2}$ is shown in Figure 3.

The ${ }^{1} \mathrm{H}-\mathrm{NMR}$ spectrum of 2 displayed two $1 \mathrm{H}$ doublet signals at $\delta 4.72$ and 4.59 with coupling constant $(J)$ of 1.5 $\mathrm{Hz}$ each that are assigned to the methylene protons (H-29). A $1 \mathrm{H}$ doublet of doublet signal at $\delta 3.15$ with coupling constants $(J)$ of 5.5 and $5.5 \mathrm{~Hz}$ was attributed to $\mathrm{H}-3$. A $1 \mathrm{H}$ multiplet signal at $\delta 3.0 \mathrm{l}$ was ascribed to $\mathrm{H}-19$. A IH doublet of doublet signal at $\delta 1.91$ with $J$ values of 5.0 and $6.5 \mathrm{~Hz}$ was accounted to $18-\mathrm{H}$ having interaction with $\mathrm{H}-19$ and $\mathrm{H}-13$. A $3 \mathrm{H}$ broad signal was associated with $\mathrm{H}-30$ methyl protons. Three broad signals at $\delta 0.99,0.84$, and 0.75 were accounted as the methyl protons attached to $\mathrm{C}-23, \mathrm{C}$ 25 . and $\mathrm{C}-27$. respectively. A $6 \mathrm{H}$ broad signal at $\delta 0.95$ was assigned to the methyl protons attached to $\mathrm{C}-24$ and $\mathrm{C}-26$. A $1 \mathrm{H}$ multiplet signal at $\delta 2.25$ was ascribed to $\mathrm{H}-5$. The remaining methylene and methine protons resonated between $\delta \mathrm{l} .58-0.93$

More conpelling evidence for the structure of 2 was provided by the analysis of its ${ }^{13} \mathrm{C}$-NMR spectrum. which showed the presence of 30 carbon atoms. The assignment of the carbon chemical shifts were made by comparison of the $\delta$ values of the corresponding carbon atoms in the structural-
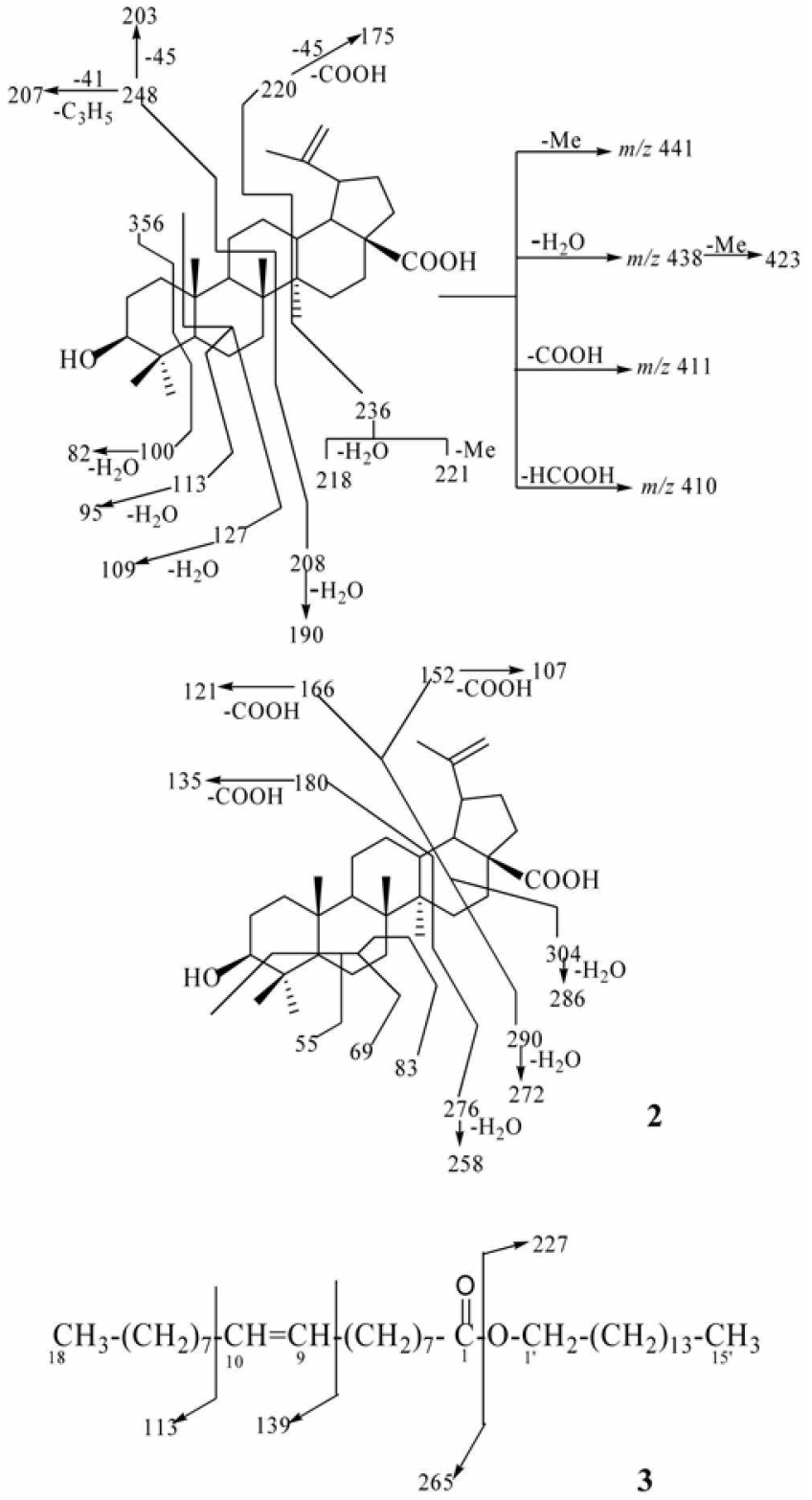

Figure 3. Fragmentation pattens of compound 2 and 3.

ly similar compounds of lupene series. ${ }^{13}$ The important signals appeared for carboxylic group at $\delta 179.80$ (C-28). vinylic carbons at $\delta 150.43(\mathrm{C}-20)$, and $\delta 110.04$ (C-29). carbinol carbon at $\delta 79.36(\mathrm{C}-3)$, and methyl carbons at $\delta$ 28.46 (C-23). 15.94 (C-24). $16.49(\mathrm{C}-25), 16.64(\mathrm{C}-26)$, 15.20 (C-27), and 19.72 (C-30). The multiplicity of each carbon was determined by the analysis of DEPT spectrum. There were six methyl, eleven methylene, six methine, and seven quaternary carbons in the molecule. The ${ }^{1} \mathrm{H} \cdot{ }^{1} \mathrm{H}$ COSY spectrum of 2 showed the connection patterns of $\mathrm{H}-19$ with $\mathrm{H}-18$ and $\mathrm{H}-21$, of $\mathrm{H}-3$ with $\mathrm{H}-2$. of $\mathrm{H}-2$ with $\mathrm{H}-1$. The HMBC spectrum of 2 exlibited ${ }^{1} \mathrm{H} \cdot{ }^{13} \mathrm{C}$ correlations of $\mathrm{C}-28$ with $\mathrm{H}-16$ and $\mathrm{H}-22$. of $\mathrm{C}-20$ with $\mathrm{H}-30$ and $\mathrm{H}-18$. of $\mathrm{C}-29$ with $\mathrm{H}_{3}-30$ and $\mathrm{H}-19$, and of $\mathrm{C}-3$ with $\mathrm{H}-2, \mathrm{H}-23$ and $\mathrm{H}-24$. On the basis of spectral data analy sis and chemical reactions. the structure of 2 has elucidated as lup-20(29)-en-18- $\beta \mathrm{H}$ - 
$3 \alpha$-ol which is a previously reported compound. ${ }^{1+4}$

Compound 3. an aliphatic ester, was obtained as a yellow gum mass from the eluent system of $\mathrm{CHCl}_{3}-\mathrm{MeOH}(95: 5)$. It decolorized bromine water which indicates the presence of unsaturated linkage(s) in the molecule. Its IR spectnum displayed characteristic absorption bands for a carbonyl group of ester $\left(172 \mathrm{~cm}^{-1}\right)$ and unsaturation $\left(1640 \mathrm{~cm}^{-1}\right)$. Its EI and FABMS spectra displayed a molecular ion peak at $m z 492$ that provides a molecular formula of $\mathrm{C}_{33} \mathrm{H}_{64} \mathrm{O}_{2}$. The prominent ion peaks generated at $m z 113\left[\mathrm{C}_{11}-\mathrm{C}_{11} \text { fission }\right]^{-}$. $139\left[\mathrm{C}_{\delta}-\mathrm{C}_{9}\right.$ fission] ${ }^{-}$, and 265 and 227 [CO-O fission] ${ }^{+}$. This suggested that an oleic acid group is esterified with a $15 \mathrm{C}$ aliphatic moiety: The fragmentation pattern of 3 is shown in Figure 3

The ${ }^{1} \mathrm{H}-\mathrm{NMR}$ spectrum of 3 displayed two $\mathrm{IH}$ multiplet signals at $\delta 5.41$ and 5.36 which were assigned to the vinylic $\mathrm{H}-9$ and $\mathrm{H}-10$. respectively. Two $1 \mathrm{H}$ doublet signals at $\delta$ $3.68(\mathrm{~J}=4.5 \mathrm{~Hz})$ and $3.65(\mathrm{~J}=4.5 \mathrm{~Hz})$ were attributed to $\mathrm{H}$ 1 'methylene protons. Another set of two $1 \mathrm{H}$ doublet signals at $\delta 2.30(J=7.5 \mathrm{~Hz})$ and $2.22(J=7.5 \mathrm{~Hz})$ was accounted to $\mathrm{H}-2$ methylene protons adjacent to the ester group. Two $2 \mathrm{H}$ multiplet signals at $\delta 2.17$ and 2.05 were ascribed to $\mathrm{H}-8$ and $\mathrm{H}-11$ methyylene protons. Two $3 \mathrm{H}$ triplet signals at $\delta 0.85 \mathrm{~J}$ $=5.5 \mathrm{~Hz})$ and $0.82(J=6.5 \mathrm{~Hz})$ were associated with the terminal $\mathrm{H}-18$ and $\mathrm{H}-15^{\prime}$, respectively. The ${ }^{13} \mathrm{C}-\mathrm{NMR}$ spectrum of 3 exhibited important signals for a carbonyl carbon at $\delta 171.37(\mathrm{C}-1)$. vinylic carbons at $\delta 130.25(\mathrm{C}-9)$ and $129.02(\mathrm{C}-10$ ), an oxygenated methy lene carbon at $\delta 70.79$ $\left(\mathrm{C}-1^{\prime}\right)$ and methyl carbons at $\delta 14.33(\mathrm{C}-18)$ and $14.26(\mathrm{C}$ 15). The multiplicity of each carbon signal was determined by DEPT experiments. The ${ }^{1} \mathrm{H}-{ }^{1} \mathrm{H}$ COSY spectrum of 3 showed correlation of vinylic $\mathrm{H}-9$ and $\mathrm{H}-10$ with $\mathrm{H}-8$ and $\mathrm{H}-$ 11. respectively. Acid hydrolysis of 3 yielded oleic acid which was confirmed by co-TLC with an authentic sample of oleic acid. On the basis of spectral data analysis and chemical reactions. the structure of 3 has been established as $n$-pentadecanyl octa-dec-19-en-oate.

\section{Experimental Section}

Chemicals. All chemicals were of an analytical grade: hexane ethyl acetate methanol. ethanol. sulphuric acid and vanillin were purchased from Daejung Chemicals and Metals (Seoul. South Korea). Pre-coated TLC plates (layer thickness $0.5 \mathrm{~mm}$ ). silica gel for column chromatography (70-230 mesh ASTM) and LiChroprep RP-18 (40-63 $\mu \mathrm{ml})$ were from Merck (Darmstadt, Gernany). Authentic standards of $\beta$ sitosterol. oleic acid. and D-glucose were purchased from Sigma-Aldrich (St. Louis. MO. USA).

Instrumentation. Melting points were determined using Electrochemical Engineering (Electrothermal. Seoul. South Korea) model IA9100 melting point apparatus. Specific rotation was measured with an instruments Ltd (Seoul. South Korea) model AA-10 polarimeter. ${ }^{1} \mathrm{H}$ - and ${ }^{13} \mathrm{C}-\mathrm{NMR}$ spectra were obtained at 500 and $125 \mathrm{MHz}$. respectively, using a Bruker Avance model DRX-500 spectrometer at the Seoul National University (SNU). Seoul. South Korea. NMR spectra were obtained in deuterated clloroform and methanol using tetrametlyylsilane (TMS) as an internal standard. with chemical shifts expressed in ppm $(\delta)$ and coupling constants $(J)$ in $\mathrm{Hz}$. EI/MS and $\mathrm{FAB} / \mathrm{MS}$ were recorded on JEOL JMS-SX 102A and JEOL JMS-AX 505WA spectrophotometers. respectively. at the Seoul National University. IR spectra were recorded on a Thermo Mattson Infinity Gold FT-IR model 60-AR spectrophotometer at the Korea Institute of Science and Technology (KIST) Seoul. South Korea.

Culture conditions. The hairy root line used in this study was previously generated by infection of $C$. roseus seedling with Agrobacteritm mizogenes $158344^{15}$ The culture media consisted of a filter-sterilized solution of $3 \%$ sucrose. halfstrength Gamborg's B5 salts and full-strength Gamborg's vitamins with the $\mathrm{pH}$ adjusted to 5.7 . The 50 - $\mathrm{mL}$ cultures were grown in $250-\mathrm{mL}$ Erlenmeyrer flasks to late exponential phase in the dark at $26^{\circ} \mathrm{C}$ at $100 \mathrm{rpm}$.

Extraction of hairy roots. The powdered hairy roots of C. roseus $(200 \mathrm{~g})$ were immersed in methanol ( 1.5 litre) for three day's at room temperature and then the supernatant was concentrated under vacuum to yield $22.5 \mathrm{~g}$ of the extract. This material was suspended in water and extracted with ethyl acetate and $n$-butanol successively to produce $11.2 \mathrm{~g}$ of ethyl acetate and $7.4 \mathrm{~g}$ of $n$-butanol extract.

Isolation of the compounds from ethyl acetate extract. The entire ethyl acetate extract was subjected to normal phase CC over silica gel ( $400 \mathrm{~g}$ ) to yield 26 fractions (each fraction $250 \mathrm{~mL}$ ) with the following eluents: fraction $1-2$ with $n$-hexane, fractions $3-4$ with $n$-hexane:ethyl acetate (9:1, v/v). fraction $5-6$ with $n$-hexane:ethyl acetate $(8: 2, v / v)$. fraction $7-8$ with $n$-hexane ethyl acetate $(7: 3 . \mathrm{v} / \mathrm{v})$, fraction 9-10 with $n$-hexane ethyl acetate $(1: 1, v / v)$. fraction 11-12 with hexane:ethyl acetate $(3: 7, v / v)$, fraction $13-14$ with ethyl acetate. fraction 15-16 with ethyl acetate:methanol $(9.5: 0.5, v / v)$, fraction $17-18$ with ethyl acetate:methanol $(9: 1, v / v)$. fraction $19-20$ with ethyl acetate methanol $(7: 3$. $\mathrm{v} / \mathrm{v})$, fraction 21-22 with ethyl acetate methanol (1:1, v/v). fraction 23-24 with ethỵl acetate:methanol $(3: 7 . \mathrm{v} / \mathrm{v})$, and fraction 25-26 in methanol. All fractions were examined by TLC. Fraction 1-4 was not further separated due to the low amount. Fraction 5-6 (0.8 g) was crystallized after the purification by $\mathrm{CC}$. and then yielded $\beta$-sitosterol $(4.20 \mathrm{mg}$ ) whose identity was confurmed through the comparison of TLC and spectroscopic data with those of an authentic sample. Fraction 7-8 $(0.6 \mathrm{~g})$ was further purified by $\mathrm{CC}$ over silica gel (100 g: each fraction of $100 \mathrm{~mL}$ ) eluting with dichloromethane and chloroform:methanol mixtures (99:1. $98.5: 1.5 .98 .2,97.5: 2.5$ and $97: 3, v / v)$ to afford one pure compound (120 mg. 2). Fraction 11-12 with hexane:ethyl acetate $(3: 7 . v / \mathrm{v})$, after re-separation with chloroform: methanol $(99: 1,99: 2.97: 3,96: 4$ and $95: 5, \mathrm{v} / \mathrm{v})$. afforded five fractions. Fraction 4 (from the eluent of $\mathrm{CHCl}_{2}: \mathrm{MeOH}$ $(96: 4 . v / v)$ ) and fraction 5 (from the eluent of $\mathrm{CHCl}_{3}: \mathrm{MeOH}$ $(95: 5 . \mathrm{v} / \mathrm{v})$ ) were re-chromatographed over Lichroprep RPI8 ODS $(50 \mathrm{~g}$ : each fraction of $50 \mathrm{~mL}$ ). The eluting was sequentially performed with methanol containing 80.60 . 40 20. 10 . and $0 \%$ of water to yield compounds 1 ( $35 \mathrm{mg}$ ) and 3 
Table 1. ${ }^{1} \mathrm{H}(500 \mathrm{MHz})$ and ${ }^{13} \mathrm{C}(125 \mathrm{MHz})-\mathrm{NMR}$ spectroscopic data of 1 in $\mathrm{MeOD}$

\begin{tabular}{|c|c|c|}
\hline Position & 'H-NMR & ${ }^{13} \mathrm{C}-\mathrm{NMR}$ \\
\hline 1 & $0.76 \mathrm{t}(6.0,3 \mathrm{H})$ & 12.05 \\
\hline 2 & 1.29 br s $(2 \mathrm{H})$ & 29.88 \\
\hline 3 & $1.58 \mathrm{~m}(\mathrm{lH})$ & 39.09 \\
\hline 4 & $\begin{array}{l}2.30 \mathrm{dd}(7.5,7.0,1 \mathrm{H}) \\
2.33 \mathrm{dd}(7.5,7.0,1 \mathrm{H})\end{array}$ & 39.97 \\
\hline 5 & $5.34 \mathrm{~m}(\mathrm{lH})$ & 130.21 \\
\hline 6 & $5.35 \mathrm{~m}(\mathrm{lH})$ & 129.91 \\
\hline 7 & $2.04 \mathrm{dd}(7.0,7.0,1 \mathrm{H})$ & 56.97 \\
\hline 8 & $5.36 \mathrm{~m}(\mathrm{lH})$ & 138.47 \\
\hline 9 & $5.34 \mathrm{~m}(\mathrm{lH})$ & 150.15 \\
\hline 10 & $3.51 \mathrm{dd}(9.0,9.0,1 \mathrm{H})$ & 70.57 \\
\hline 11 & $1.52 \mathrm{~m}(\mathrm{lH})$ & 29.88 \\
\hline 12 & 1.29 br s $(2 \mathrm{H})$ & 22.88 \\
\hline 13 & $1.34 \mathrm{brs}(2 \mathrm{H})$ & 24.55 \\
\hline 14 & $1.25 \mathrm{brs}(2 \mathrm{H})$ & 33.91 \\
\hline 15 & $1.60 \mathrm{~m}(\mathrm{IH})$ & 42.53 \\
\hline 16 & 1.29 br s $(2 \mathrm{H})$ & 34.48 \\
\hline 17 & $\begin{array}{l}1.60 \mathrm{~m}(\mathrm{IH}) \\
1.48 \mathrm{~m}(\mathrm{lH})\end{array}$ & 36.91 \\
\hline 18 & 3.46 ddd $(3.5,5.5,4.0,1 \mathrm{H})$ & 70.45 \\
\hline 19 & $2.00 \mathrm{dd}(5.5,6.6,1 \mathrm{H})$ & 50.37 \\
\hline 20 & $5.35 \mathrm{~m}(\mathrm{lH})$ & 128.10 \\
\hline 21 & $5.36 \mathrm{~m}(\mathrm{lH})$ & 122.26 \\
\hline 22 & $\begin{array}{l}2.05 \mathrm{dd}(7.0,7.0,1 \mathrm{H}) \\
2.02 \mathrm{dd}(7.0,5.5,1 \mathrm{H})\end{array}$ & 37.48 \\
\hline 23 & $1.56 \mathrm{~mm}(\mathrm{lH})$ & 29.95 \\
\hline 24 & 1.25 br s $(2 \mathrm{H})$ & 27.43 \\
\hline 25 & $1.25 \mathrm{brs}(2 \mathrm{H})$ & 32.07 \\
\hline 26 & $1.25 \mathrm{br} \mathrm{s}(2 \mathrm{H})$ & 32.13 \\
\hline 27 & $1.48 \mathrm{~m}(\mathrm{lH})$ & 39.03 \\
\hline 28 & 0.67 br s $(3 \mathrm{H})$ & 19.54 \\
\hline 29 & $0.78 \mathrm{~d}(6.0)(3 \mathrm{H})$ & 14.31 \\
\hline 30 & $0.91 \mathrm{~d}(6.0)(3 \mathrm{H})$ & 21.43 \\
\hline 31 & $0.80 \mathrm{~d}(6.5)(3 \mathrm{H})$ & 19.09 \\
\hline 32 & $\begin{array}{l}3.84 \mathrm{~d}(6.5)(1 \mathrm{H}) \\
3.81 \mathrm{~d}(6.5)(1 \mathrm{H})\end{array}$ & 63.73 \\
\hline 33 & $0.89 \mathrm{~d}(6.5)(3 \mathrm{H})$ & 18.44 \\
\hline 34 & $0.86 \mathrm{~d}(7.0)(3 \mathrm{H})$ & 18.90 \\
\hline 35 & 0.67 br s $(3 \mathrm{H})$ & 15.07 \\
\hline $\mathrm{l}^{\prime}$ & $4.36 \mathrm{~d}(8.0,1 \mathrm{H})$ & 101.45 \\
\hline $2^{\prime}$ & $4.32 \mathrm{~d}(3.5,1 \mathrm{H})$ & 76.46 \\
\hline 3 & $3.44 \mathrm{dd}(4.0,3.5,1 \mathrm{H})$ & 74.03 \\
\hline $4^{\prime}$ & $3.46 \mathrm{dd}(3.5,5.5,1 \mathrm{H})$ & 73.74 \\
\hline 5 & $3.54 \mathrm{~mm}(\mathrm{lH})$ & 79.83 \\
\hline 6 & $\begin{array}{l}3.02 \mathrm{~d}(6.5,1 \mathrm{H}) \\
3.00 \mathrm{~d}(6.5,1 \mathrm{H})\end{array}$ & 63.10 \\
\hline $\mathrm{CH}_{3} \mathrm{COO}$ & $2.40 \mathrm{br} s(3 \mathrm{H})$ & $\begin{array}{l}174.53(\mathrm{CO}) \\
34.43(\mathrm{Me}-\mathrm{C})\end{array}$ \\
\hline
\end{tabular}

$J$ Falues (in $\mathrm{Hz}$ ) are in parenthesis

(23 $\mathrm{mg}$ ). The separation of compounds of other fractions is in progress.

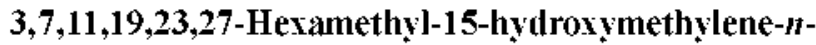
octacos-5,8,20-triene-10 $\beta, 18 \alpha$-diol-10 $\beta$-D-glucopyrano- side (1). Light yellow semisolid. $[\alpha]_{\mathrm{D}}^{\hat{3}}+21.5^{\circ}$ (c) 0.12 , $\mathrm{MeOH}): \mathrm{IR}(\mathrm{KBr}) v_{\text {max }}: 3420.3390,3285.2926,2853$. 1736. 1640, 1463,1376,1174, 1082, 1053, $1021 \mathrm{~cm}^{-1}$. EIMS $m z$ (rel. int.): $532\left[\mathrm{M}-\mathrm{C}_{6} \mathrm{H}_{1} \mathrm{O}_{5}-\mathrm{CH}_{3} \mathrm{CO}\right](1.7), 476$ (2.5). $462(2.6), 448(2.7), 436(4.1), 420(2.7), 408(3.6)$. $407(3.8) .382(14.5) .381(19.2), 353(100), 352$ (75.9), 324 (14.9). 323 (18.3). 295 (12.3). 282 (5.7). 251 (48.3). 238 (15.0). 210 (38.3), 209 (16.2), 181 (13.8), 180 (17.3), 152 (18.2), 151 (17.9), 127 (21.2), 125 (34.8), 113 (28.6), 97 (57.0). 85 (47.7). 71 (65.3). 57 (83.9): FAB-MS (positive mode) $[\mathrm{M}+\mathrm{H}]^{-}$mz: $\left.739[\mathrm{M}]^{+}\left(\mathrm{C}_{43} \mathrm{H}_{79} \mathrm{O}_{9}\right)\right]^{+}$: ${ }^{1} \mathrm{H}$ and ${ }^{13} \mathrm{C}$ NMR (Table 1).

3-Epibetulinic acid (2). Colourless solid: IR ( $\mathrm{KBr}) v_{\text {max }}$ : $3448,2940,2852,1688,1640,1452,1378,1237,1038,884$ $\mathrm{cm}^{-1} ;{ }_{1}^{1} \mathrm{H}-\mathrm{NMR}(500 \mathrm{MHz}$. MeOD): $\delta .4 .72(\mathrm{lH}, \mathrm{d}, J=1.5$ Hz. Hz-29a). 4.59 (l H. d. $J=1.5 \mathrm{~Hz}, \mathrm{H}_{2}-29$ b). 3.15 (lH. dd, $J$ $=5.5 .5 .5 \mathrm{~Hz} . \mathrm{H}-3 \beta) .3 .01(\mathrm{lH} . \mathrm{m} . \mathrm{H} \cdot 19 \beta) .2 .25(\mathrm{lH}, \mathrm{m} . \mathrm{H}-$ $5(\alpha) .1 .91$ (lH. dd, $J=5.0 .6 .5 \mathrm{~Hz} . \mathrm{H}-18 \alpha) .1 .58(1 \mathrm{H}, \mathrm{m} . \mathrm{H}-$ $13 \beta), 1.69(3 \mathrm{H}$, br s. Me-30), 0.99 (3H, br s. Me-23). 0.95 $(6 \mathrm{H}$. br s. Me-24. Me-26). 0.84 (3H. br s. Me-25). $0.75(3 \mathrm{H}$. br s. Me-27): ${ }^{12} \mathrm{C}-\mathrm{NMR}$ (125 MHz: MeOD): $\delta 39.14$ (C-1). 27.61 (C-2). 79.36 (C-3). 39.66 (C-4). 56.30 (C-5). 19.05 (C-6). 35.15 (C-7), 41.47 (C-8). 51.43 (C-9). 37.92 (C-10). 21.67 (C-11). 26.36 (C-12). 39.56 (C-13). 43.19 (C-14). 31.33 (C-15). 33.03 (C-16). 57.03 (C-17). 47.85 (C-18). 50.03 (C-19). 151.43 (C-20). 30.43 (C-21). 37.85 (C-22). 28.46 (C-23). 15.94 (C-24). 16.49 (C-25), 16.64 (C-26). 15.20 (C-27). 179.80 (C-28). 110.04 (C-29). 19.72 (C-30): EIMS $\mathrm{n} / \mathrm{z}$ (rel. int.): $456\left[\mathrm{M}^{-}\left(\mathrm{C}_{30} \mathrm{H}_{48} \mathrm{O}_{3}\right)(64.8) .441\right.$ (7.4), 438 (30.2), 423 (14.9). 411 (9.1), 395 (13.9). 369 (4.5). 356 (2.9). $327(3.4) .317(6.8) .302(9.7) .287(4.7) .259(9.9)$. $348(54.6) .233(30.4), 220(32.2) .207(61.7) .203$ (33.0). 189 (100). 175 (29.4). 161 (17.1). 147 (20.1). 135(37.8). 121 (29.2). 119 (27.7). 95 (31.0). 81 (27.8). 69 (22.1). 55 (18.8): Positive ion FABMS $m z \quad 457\left[\mathrm{C}_{30} \mathrm{H}_{49} \mathrm{O}_{3}\right]^{-}$: negative ion FABMS $m z 455\left[\mathrm{C}_{30} \mathrm{H}_{47} \mathrm{O}_{3}\right]^{+}$.

n-Pentadecanyl octa-dec-19-en-oate (3). Yellow gum: IR (KBr) v v11ax: 2922. 2853. 1721. 1640. 1462. 1254. 1106. $748 \mathrm{~cm}^{-1}:{ }^{1} \mathrm{H}-\mathrm{NMR}\left(500 \mathrm{MHz}: \mathrm{CDCl}_{3}\right): \delta 5.4 \mathrm{l}(\mathrm{lH}, \mathrm{m}, \mathrm{H}-$ 9). $5.36(1 \mathrm{H}, \mathrm{m}, \mathrm{H}-10) .3 .68\left(1 \mathrm{H}, \mathrm{d}, J=4.5 \mathrm{~Hz}, \mathrm{H} 2-\mathrm{l}^{\prime} \mathrm{a}\right), 3.65$ (1H. d. $J=4.5 \mathrm{~Hz}$. H-l'b). 2.33 (1H. d. $J=7.5 \mathrm{~Hz} . \mathrm{H}-2 \mathrm{a})$. $2.22\left(1 \mathrm{H}\right.$, d. $\left.J=7.5 \mathrm{~Hz}, \mathrm{H}_{2}-2 \mathrm{~b}\right), 2.17\left(2 \mathrm{H}, \mathrm{m}, \mathrm{H}_{2}-8\right) .2 .05$ $\left(2 \mathrm{H} . \mathrm{m} . \mathrm{H}_{2}-1 \mathrm{l}\right), 1.61\left(2 \mathrm{H}, \mathrm{m} . \mathrm{H}_{2}-3\right) .1 .25(46 \mathrm{H}$. br s. $23 \mathrm{x}$ $\left.\left.\mathrm{CH}_{2}\right) .0 .85(3 \mathrm{H}, \mathrm{t}, J=5.5 \mathrm{~Hz}), \mathrm{Me}-18\right), 0.82(3 \mathrm{H}, \mathrm{t}, J=6.5$ $\left.\mathrm{Hz}, \mathrm{Me}-15^{\prime}\right) ;{ }^{13} \mathrm{C}-\mathrm{NMR}\left(125 \mathrm{MHz} . \mathrm{CDCl}_{3}\right): \delta 17 \mathrm{l} .37(\mathrm{C}-\mathrm{l})$, 130.25 (C-9), $129.02(\mathrm{C} \cdot 10), 70.79\left(\mathrm{C} \cdot \mathrm{I}^{\prime}\right), 38.96\left(\mathrm{CH}_{2}\right)$. $36.16\left(\mathrm{CH}_{2}\right) .33 .94\left(\mathrm{CH}_{2}\right), 32.14\left(\mathrm{CH}_{2}\right), 30.59\left(\mathrm{CH}_{2}\right), 30.38$ $\left(\mathrm{CH}_{2}\right), 29.92\left(\mathrm{CH}_{2}\right) .29 .82\left(\mathrm{CH}_{2}\right), 29.67\left(7 \times \mathrm{CH}_{2}\right) .29 .58$ $\left(\mathrm{CH}_{2}\right), 29.54\left(\mathrm{CH}_{2}\right), 29.48\left(\mathrm{CH}_{2}\right), 29.33\left(\mathrm{CH}_{2}\right) .29 .15\left(\mathrm{CH}_{2}\right)$. $28.94\left(\mathrm{CH}_{2}\right) .27 .44\left(\mathrm{CH}_{2}\right), 26.93\left(\mathrm{CH}_{2}\right), 25.85\left(\mathrm{CH}_{2}\right), 24.94$ $\left(\mathrm{CH}_{2}\right), 23.20\left(\mathrm{CH}_{2}\right) .22 .91\left(\mathrm{CH}_{2}\right), 14.33(\mathrm{Me}-18) .14 .26$ (Me-15); EIMS: $m z$ (rel. int.): $492\left[\mathrm{M}^{-}\left(\mathrm{C}_{32} \mathrm{H}_{64} \mathrm{O}_{2}\right]\right.$ (1.2). $463(5.3), 435$ (10.1), 393 (13.2). 281 (15.9), $265(7.8), 251$ (16.1), $227(5.3), 223(14.3), 167(46.9), 149(40.3), 139$ (26.3). 113 (40.7). $111(59.7) .97(64.9) .83(74.7) .69(70.0)$. $57(100)$

Acid hydrolysis of 1 . Compound 1 (6 mg) was refluxed 
with $2 \mathrm{~mL}$ of $1 \mathrm{M}$ hydrochloric acid:dioxane $(\mathrm{l}: \mathrm{L} . \mathrm{v} / \mathrm{v})$ in a water bath for $4 \mathrm{~h}$. The reaction mixture was evaporated to dryness and partitioned with chloroform and water four times. and each extract was concentrated. The chloroform extract contained the aglycone portion. while the water extract contained D-glucose (co-chromatographed on TLC with an authentic sample).

Acknowledgements. This study was supported by technology development program for Agriculture and Forestry. Ministry of Agriculture and Forestry. Rep. of Korea. The authors wish to acknowledge in the financial support of the Rural Development Administration (RDA) made in the Biogreen 21 project year of 2005

\section{References}

1. Taylor. W. I.: Farnsworth. N. R. The Cathoranthus Alkaloids: Marcel Dekker: New York: 1975.

2. Chockalingam. S: Nalina Sundari, M. S: Themnozhi. S. $J$.
Eniront. Biol. 1989.10 .303

3. Luijendijk. T. I. C.: Van der. M. E.: Verpoote. R. J. Chemical Ecology 1996. 22. 1355.

4. Leveque. D.: Wilhlm. T. Jehl. F. Buhl Cancer 1996. 83.176.

5. Farnsworth, N. R. Jounal of Sanural Products 1961. 2t, 105.

6. Daniel. M.: Sabnis. S. D. Indian J. Exp. Biologv 1978. 16. 512.

7. Nishibe. S: Takenaka. T.; Fujikawa. T: Yasukawa, K: Takido. M.: Moritsu. Y.: Hirota. A.: Kawamura. K.: Noro. Y. Natural Medicine (Tokyo) 1996.50.378.

8. Van der. H. R.: Verpoote. R.: Ten Hoopen. H. J. G. Plam Cell Tiss. Org. Cult. 1989. 18.231.

9. Moreno. P. R. H: Van der, H. R:; Verpoorte. R. Plant Cell Tiss. Org. Cult $1995,+2,1$.

10. Moreno. P. R. H.: Poulsen. C.: Heijden. R. V.: Verpoorte. R. Enzme and Hicrobial Techolog: 1996. 18.99.

11. Knobloch. K. H.: Bast. G.: Berlin. J. Phwochentistry 1982. 21. 591 .

12. Seitz. H. U.; Eilert. U.: De Lucam, V.: Kurz. W. G. W. Plan Cell Tiss. Org. Cult. 1989. 18.71.

13. Mahato. S. B.: Kundu. A. B. Phytochemistry 1994. 37.1517.

14. Kitajima. J.: Shindo. M.: Tanaka. Y. Chem. Phamt. Bull. 1990. 38. 714 .

15. Bhadra. R.: Vani, S.: Shanks. J. Biotechol Biong. 1993. 41, 581 . 